\title{
Hypogaeic pitfall traps: methodological advances and remarks to improve the sampling of a hidden ant fauna
}

\author{
F. A. Schmidt $\cdot$ R. R. C. Solar
}

Received: 22 June 2009/Revised: 14 December 2009/ Accepted: 1 February 2010/Published online: 9 March 2010

(C) International Union for the Study of Social Insects (IUSSI) 2010

\begin{abstract}
Ant assemblages present a great vertical stratification, with microhabitats showing strong differences in relation to species composition. Among the microhabitats, the hypogaeic has been poorly studied. Hypogaeic or subterranean ants live in the deeper soil layers, which make the sampling logistics and operability a difficult work. The fact that the hypogaeic ant fauna is diversified and abundant, with low similarity to ant assemblages in other microhabitats, has promoted the development of several collecting techniques to sample this hidden ant fauna. Here, we verify the ability of hypogaeic pitfall traps to sample subterranean ants. In addition, we propose methodological advances and remarks about the use of this ant sampling technique.
\end{abstract}

Keywords Collecting techniques · Formicidae · Hypogaeic ants

\section{Introduction}

Ants (Hymenoptera: Formicidae) represent an abundant and speciose insect group with a wide geographic distribution and, together with termites, they comprise more than half of the total insect biomass (Wilson and Hölldobler, 2005). At this moment, there are about 12,600 ant

F. A. Schmidt $(\bowtie) \cdot$ R. R. C. Solar

Departamento de Biologia Animal, Programa de Pós-Graduação em Entomologia. Laboratório de Ecologia de Comunidades, Universidade Federal de Viçosa, Viçosa, MG 36570-000, Brazil e-mail: schmidt.fa@gmail.com

R. R. C. Solar

e-mail: rrsolar@gmail.com species already described (25 January 2010) (Agosti and Johnson, 2005) and this number has been estimated to reach 20,000 species (Hölldobler and Wilson, 1990).

Thus, ants are important elements of terrestrial ecosystems, involved in mutualistic associations with plants, other insects and many kinds of organisms (Schultz and McGlynn, 2000; Oliveira and Del-Claro, 2005). Moreover, ants impressively contribute to edaphic processes such as water and soil movement and nutrient cycling (Lobry de Bruyn, 1999; Sousa-Souto et al., 2007). Therefore, many studies have used ants as models in ecological surveys (Agosti et al., 2000) and suggest the use of these insects as bioindicators of different disturbances (Underwood and Fisher, 2006).

Hence, different collecting techniques have been developed (Bestelmeyer et al., 2000) to offer a representative, repeatable and unbiased sampling effort of ant faunas, allowing safe results about the ecology of ant communities. However, among ant biodiversity and community studies, collecting techniques have often focused mainly on specific microhabitats, particularly the epigaeic and arboreal ones (e.g. Greenslade and Greenslade, 1971; Olson, 1991; Orbist and Duelli, 1996; Agosti et al., 2000; Wang et al., 2001; Ribas et al. 2003a; Ribas et al., 2005; Elisson et al., 2007). Hypogaeic or subterranean ants are seldom studied, because these ants live in the lower soil layers, which make the logistics and operability of the sampling effort a difficult work. Despite these sampling difficulties, studies have shown that species composition of hypogaeic ant assemblages is completely different from the ant fauna sampled in other microhabitats (e.g. epigaeic and arboreal) (Silva and Silvestre, 2004; Wilkie et al., 2007; Schmidt and Diehl, 2008).

Furthermore, as well as ants inhabiting the canopies of tropical forests, hypogaeic ants probably compose a large 
part of ant species that have not been described yet. Recent data, such as the description of Martialis heureka Rabeling et al., 2008, also indicate that hypogaeic microhabitats host phylogenetically ancient and conserved ant lineages. This means that hypogaeic habits probably evolved early during the evolution of ants (Rabeling et al., 2008). Thus, ants from hypogaeic microhabitats represent the greatest frontier for the knowledge of ant diversity which has encouraged some authors to develop collecting techniques to sample these ants (Weissflog et al., 2000; Berghoff et al., 2002, 2003a; Wilkie et al., 2007).

The collecting techniques for hypogaeic ants developed in the studies cited above, in general, used baits in small recipients or probes that could be buried into the soil. Thus, ants that live in lower soil layers could be attracted to the baits.

Moreover, modified pitfall traps (hypogaeic pitfall traps) have been developed to sample subterranean ants (e.g. Berghoff et al., 2003b). However, it was proposed as a specific technique, without the character of a standard method to sample subterranean ants. Hence, hypogaeic pitfall traps is a known ant sampling technique, but few efforts have been employed to improve its versatility and standard use.

In this paper, we verify the ability of hypogaeic pitfall traps to sample subterranean ants. In addition, we propose methodological advances and remarks to enhance the standard using of this ant sampling technique. Still, we provide a framework to standardize the technique.

\section{Materials and methods}

Hypogaeic pitfall trap design and installation

The pitfall traps consist of plastic recipients (diameter $8 \mathrm{~cm}$; height $12 \mathrm{~cm}$ ) with four radial holes $(1 \mathrm{~cm}$ diameter) made at a height of $6 \mathrm{~cm}$ in the plastic recipient, which allow ants to access the interior of the trap (Fig. 1). In the inner of the pitfall trap, if the study aims to use attracting baits, a smaller plastic recipient may be attached (the bottom of a $500 \mathrm{ml}$ water pet bottle cut at $7 \mathrm{~cm}$ height) where we set two small plastic pots (e.g. empty boxes of photographic films, $3.3 \mathrm{~cm}$ diameter; $5.0 \mathrm{~cm}$ height). One of the small plastic pots is filled with sardine $\left(5 \mathrm{~cm}^{3}\right)$ and the other with honey $\left(10 \mathrm{~cm}^{3}\right)$. In the space between the inner recipient and the pitfall wall we put $200 \mathrm{ml}$ of a liquid solution, water, glycerol $(5 \%)$ and salt $(0.9 \%)$, which kept and killed the ants and prevented them from reaching the baits. The traps were closed with their plastic lids to prevent the soil from entering into the pitfall and disturbing the sampling.

A string with a colored ribbon was tied to the pitfall to help find the place where the hypogaeic pitfall was buried in the field. The hypogaeic pitfall traps were buried in the soil, in such a way that the recipient bottom is fixed at $20 \mathrm{~cm}$ depth (but see "Methodological remarks"). We made a uniform hole by the use of a post hole digger to prevent huge alterations on the soil structure.

We removed the pitfall traps after $48 \mathrm{~h}$ with the help of a small shovel. Furthermore, to avoid the spilling of the

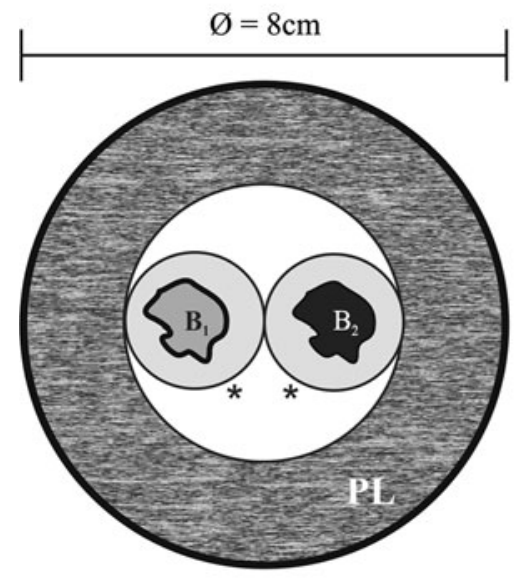

Upper View
Fig. 1 Hypogaeic pitfall trap design. Upper view Larger plastic recipient (diameter $8 \mathrm{~cm}$ ) and in the inner part, the smaller plastic recipient (bottom of $500 \mathrm{ml}$ mineral water pet bottle cut at $7 \mathrm{~cm}$ height) where we set two small plastic pots (e.g. empty boxes of photographic film, $3.3 \mathrm{~cm}$ diameter; $5.0 \mathrm{~cm}$ height) each one contain
Lid

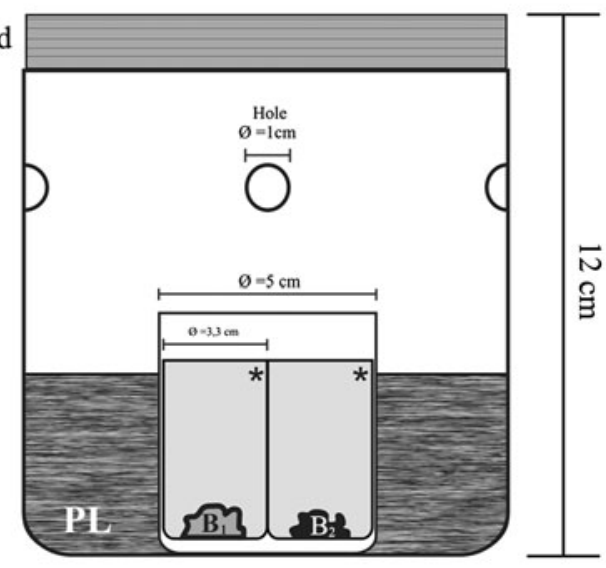

Side View
${ }^{\star}$ Disposable parts

the baits, represented by $\mathrm{B}_{1}$ and $\mathrm{B}_{2}$ (in this case, sardine and honey). Side view Large plastic recipient (height $12 \mathrm{~cm}$ ) with four radial holes $(1 \mathrm{~cm}$ diameter) made at $6 \mathrm{~cm}$ height, which allow ants to access the trap. Asterisks represent the disposable parts, if it is decided not to use the baits. PL preservative liquid 
solution with ants, it is necessary to pass an adhesive strap in the holes of the trap. Otherwise, the content can be transferred to a hermetic recipient.

\section{Sampling ants}

We verified the ability of hypogaeic pitfall traps to sample subterranean ants in Viçosa, Minas Gerais State, southeastern Brazil. The landscape of the region is characterized by forests fragments described as semideciduous seasonal rainforest (Veloso et al., 1991), a forest formation of Atlantic Rain Forest biome (IBGE, 2004), crop areas (mainly coffee), pasture and forestry (Valverde, 1958; Fundação Centro Tecnológico de Minas Gerais-CETEC, 1983; Ribas et al., 2003b).

Between January and February 2007 the pitfall traps were placed at eight areas, one pasture and seven forest remnants at distinct restoration time (years) ranging from 7 to 120 years. In each area, we set the pitfall traps in ten sampling units along a $100 \mathrm{~m}$ transect and the distance between one sampling unit and the other was $10 \mathrm{~m}$. The pitfall traps remained in the field for $48 \mathrm{~h}$.

\section{Identification of ant species}

We sorted out and identified the collected ants by genera with the help of the identification keys of Bolton (1994) and Palacio and Fernandéz (2003). We adopted the subfamily classification suggested by Bolton (2003).

Species identification was carried out by comparing species to the Formicidae reference collection of the Laboratório de Ecologia de Comunidades-UFV, where all voucher specimens were deposited, and according to taxonomic keys and genera revision papers available at antbase.org (Agosti and Johnson, 2005).

\section{Results and discussion}

In all areas (pasture and forests) we collected 29 ant species from 14 genera and 7 subfamilies. The more speciose subfamily was Myrmicinae (20 species), followed by Formicinae (3 species), and Ecitoninae (2 species). Cerapachyinae, Dolichoderinae, Ectatomminae and Ponerinae were each represented by only one species (Table 1).

The apparently low number of ant species (29) sampled by the hypogaeic pitfall trap is within the range of the number of species (16-47) reported in other studies in the hypogaeic microhabitat (Fowler and Delabie, 1995; Fowler et al., 2000; Wilkie et al., 2007; Schmidt and Diehl, 2008). Nevertheless, Delabie and Fowler (1995), Berghoff et al. (2003a, b) and Silva and Silvestre (2004) reported a higher number of ant species (from 71 to 113) in areas where vegetation has an expressive structural complexity such as the Atlantic Coastal Rainforest and the Equatorial Forest.

Even though we had collected a relatively small number of ant species with hypogaeic pitfall traps, compared to epigaeic/arboreal samples, this technique allows the sampling of some remarkable ant species. For example, Acanthostichus laticornis Forel, 1908, belongs to a group of predominantly predatory hypogaeic ants that is rarely recorded by other ant colleting techniques (MacKay, 1996) and Carebara urichi (Wheeler, 1922) and Carebara gr. lignata, ants of a group, the identification of which is considerably difficult because of the small size of the specimens. Some other remarkable samplings have been made with the use of this trap in different sites of Minas Gerais State, as Simopelta curvata (Mayr, 1887), Cheliomyrmex pr. morosus Mayr, 1870, ants of genus Acropyga Roger, 1862, and at least two other species of the genus Acanthostichus Mayr, 1887 (Solar and Schmidt, pers. comm.).

Moreover, the greatest surprise about the ant fauna sampled by hypogaeic pitfall trap was the sampling of $\mathrm{Si}$ mopelta minima (Brandão, 1989). This species was collected for the first time in 1986-1987 and has never been recorded since then. This fact encouraged Brazilian environmental institutions to consider S. minima as extinct (MMA, 2007), consisting in the first register of an extinction of an ant species in the world by human activities.

The records of the ant taxa described above, which are considered rare and collected with difficulty mainly by the use of epigaeic sampling techniques, highlight the discussion about the geographical distribution and conservation status of ant species (Brandão et al., 2008). Thus, the possible biological and collecting rarity of some ants could be just a methodological sampling artifact. Since the hypogaeic pitfall trap began to be used systematically, rare ant taxa have been amply and constantly sampled, because this collecting technique is more suitable to sample ants with a subterranean lifestyle.

Hence, knowledge about rarity, status of conservation of subterranean ant species and their response to ecological or environmental processes and human activities, could be improved by sampling techniques, such as hypogaeic pitfall traps, which offer a representative, repeatable and unbiased sampling effort of subterranean ant fauna. Moreover, this technique permits to test more intricate hypotheses about the role of hypogaeic microhabitat on the structure and dynamic of local ant communities and about the natural history of this hidden ant fauna.

\section{Methodological remarks}

The installation of the hypogaeic pitfall traps in our study followed some standard parameters. However, different parameters can be adopted, depending on the aim of the ant 
Table 1 Ants collected by hypogaeic pitfall traps at one pasture (0) and seven forest remnants at distinct restoration time (years) ranged from 7 to 120 years, in Viçosa, State of Minas Gerais, southeastern Brazil

\begin{tabular}{|c|c|c|c|c|c|c|c|c|}
\hline Taxa & 0 & 7 & 20 & 30 & 40 & 50 & 80 & 120 \\
\hline \multicolumn{9}{|l|}{ Cerapachyinae } \\
\hline Acanthostichus laticornis Forel, 1908 & - & - & - & - & $\mathrm{X}$ & - & - & - \\
\hline \multicolumn{9}{|l|}{ Dolichoderinae } \\
\hline Linepithema aztecoides Wild, 2007 & $\mathrm{X}$ & $X$ & - & - & $X$ & - & - & - \\
\hline \multicolumn{9}{|l|}{ Ecitoninae } \\
\hline Labidus mars Forel, 1912 & - & - & - & - & $X$ & - & $\mathrm{X}$ & - \\
\hline Labidus praedator (Fr. Smith, 1858) & - & - & - & - & $X$ & $\mathrm{X}$ & - & - \\
\hline \multicolumn{9}{|l|}{ Ectatomminae } \\
\hline Ectatomma edentatum Roger, 1863 & - & - & - & $X$ & $X$ & - & - & $X$ \\
\hline \multicolumn{9}{|l|}{ Formicinae } \\
\hline Brachymyrmex sp. A & - & - & $X$ & - & - & - & - & $\mathrm{X}$ \\
\hline Camponotus (Myrmothrix) cingulatus Mayr, 1862 & - & - & - & - & - & - & $\mathrm{X}$ & - \\
\hline Camponotus (Myrmaphaenus) novogranadensis Mayr, 1870 & - & $\mathrm{X}$ & - & - & - & - & - & - \\
\hline \multicolumn{9}{|l|}{ Myrmicinae } \\
\hline Atta sexdens rubropilosa Forel, 1908 & - & - & $\mathrm{X}$ & - & $X$ & - & - & - \\
\hline Carebara urichi (Wheeler, 1922) & - & - & - & - & $\mathrm{X}$ & - & - & $\mathrm{X}$ \\
\hline Carebara gr. lignata sp. A & - & - & - & $X$ & - & - & - & - \\
\hline Octostruma simoni (Emery, 1890) & - & - & - & $\mathrm{X}$ & - & - & - & - \\
\hline Pheidole sp. A & - & - & - & - & - & $X$ & - & - \\
\hline Pheidole sp. B & - & - & - & $X$ & - & - & - & - \\
\hline Pheidole sp. D & $\mathrm{X}$ & - & $X$ & - & - & - & - & - \\
\hline Pheidole sp. J & - & - & - & - & - & - & - & $X$ \\
\hline Pheidole sp. $\mathrm{N}$ & - & - & - & - & - & - & $\mathrm{X}$ & - \\
\hline Rogeria micromma Kempf, 1961 & - & - & - & $X$ & - & - & - & - \\
\hline Solenopsis saevissima (Fr. Smith, 1855) & $\mathrm{X}$ & $\mathrm{X}$ & - & - & - & - & - & - \\
\hline Solenopsis gr. geminata sp. A & $\mathrm{X}$ & - & - & - & - & - & - & - \\
\hline Solenopsis sp. B & - & - & $X$ & - & $X$ & - & - & - \\
\hline Solenopsis sp. C & - & - & $\mathrm{X}$ & $X$ & $X$ & $X$ & $X$ & $X$ \\
\hline Solenopsis sp. E & $\mathrm{X}$ & - & - & - & - & - & $X$ & $X$ \\
\hline Solenopsis sp. F & - & - & - & - & - & - & - & $X$ \\
\hline Solenopsis sp. L & - & - & - & $X$ & - & - & - & - \\
\hline Solenopsis sp. H & - & - & $X$ & $X$ & - & - & - & $X$ \\
\hline Solenopsis sp. M & - & - & - & - & $X$ & - & $\mathrm{X}$ & $\mathrm{X}$ \\
\hline Wasmannia auropunctata (Roger, 1863) & - & $X$ & - & - & $\mathrm{X}$ & $X$ & - & - \\
\hline \multicolumn{9}{|l|}{ Ponerinae } \\
\hline Simopelta minima (Brandão, 1989) & - & $\mathrm{X}$ & - & - & - & - & - & - \\
\hline
\end{tabular}

survey. Therefore, we list some parameters of the installation of the hypogaeic pitfall traps that could be changed according to the aim of the study.

\section{The installation of the traps at $20 \mathrm{~cm}$ depth}

Samplings of hypogaeic ants have been done at 5-25 cm depth (Delabie and Fowler, 1995; Fowler and Delabie, 1995; Fowler et al., 2000; Berghoff et al., 2002; Berghoff et al., 2003a; Silva and Silvestre, 2004). However, Wilkie et al. (2007), sampling subterranean ants at different depths (from 12.5 to $50 \mathrm{~cm}$ ), reported a pronounced stratification of the subterranean ant fauna at different soil depths. Thus, as our aim was to verify if hypogaeic pitfall trapping is suitable to sample subterranean ants, we chose as standard depth $20 \mathrm{~cm}$, a soil layer that has been reported to host a variety of hypogaeic ants. Nevertheless, the physical dimensions of hypogaeic pitfall traps permit their use also in studies focused on subterranean ant stratification in soil depths in a pile at a single site, as Wilkie et al. (2007) or randomly placed among sites at different depths. 


\section{The use of attractive baits}

We used attractive baits in pitfall traps to increase the ant fauna sampling. Although in lower soil layers the smell of baits could play an even less pronounced role for ants, their use is still recommended by other studies (Berghoff et al., 2003a; Wilkie et al., 2007). A shortcoming of baits is that they are not attractive to all of the ant species (Porter, 2005). However, unbaited pitfalls could be recommended for more unbiased samplings (T. Marques, pers. comm.).

\section{The use of killing solution}

We used a killing solution to ensure that all ant species attracted will be inside the trap at the moment of removal. The use of a killing solution does not allow the ants to reach the baits and to recruit afterwards; however, our aim was merely to sample and account for the number of ant species. Thus, for the sake of species registration, a single ant individual attracted to the trap is ultimately sufficient. However, the trap could also be used without a killing solution, but in this way it will have the same methodological framework of buried baits in small recipients or probes as described by Berghoff et al. (2002) and Wilkie et al. (2007).

\section{The time pitfall traps remained in the field (48 h)}

In general pitfall traps used at ground surface are left in the field for 2 or 3 days, which allows a sufficient capture of ant species and in the case of hypogaeic microhabitat this time is enough for the ants to rebuild their tunnels. Thus, as we used hypogaeic pitfall traps in association with others pitfall traps installed at epigaeic and arboreal microhabitats, the $48 \mathrm{~h}$ was used as a standard time for ant sampling in all microhabitats during our study. However, other research groups have left the hypogaeic pitfall traps in the field for a longer time (e.g. 7 days) and they used a solution of glycerol (5\%) and ethanol $(70 \%)$ in the inner part of the traps to promote a better conservation of ant specimens (Vasconcelos H.L., pers. comm.).

Acknowledgments Thanks to the farmers of Viçosa city and Universidade Federal de Viçosa for allowing access the forests and pasture in their properties. We are indebted to Carla R. Ribas for helping at fieldwork and Rodrigo Feitosa for his helping to confirm the ant identification. We are thankful to Renata Campos, Rodrigo Feitosa, Carla R. Ribas, José H. Schoereder, and two anonymous referees for critical reading of previous versions of the manuscript and to Heraldo L. Vasconcelos and Tatianne Marques who provided replying about further using of this pitfall. We also thank CAPES, $\mathrm{CNPq}$ and FAPEMIG for financial support and grants.

\section{References}

Agosti D. and Johnson N.F. 2005. Antbase. World Wide Web Electronic Publication. antbase.org, version (05/2005), Accessed 25 Jan. 2010

Agosti D., Majer J.D., Alonso L.E., and Schultz T.R. 2000. Ants: Standard Methods for Measuring and Monitoring Biodiversity. Smithsonian Institution Press, Washington, $280 \mathrm{pp}$

Berghoff S.M., Maschwitz U. and Linsenmair K.E. 2003a. Hypogaeic and epigaeic ant diversity on Borneo: evaluation of baited sieve buckets as a study method. Trop. Zool. 16: 153-163

Berghoff S.M., Maschwitz U. and Linsenmair K.E. 2003b. Influence of the hypogeic army Dorylus (Dichthadia) laevigatus on tropical arthrop communities. Oecologia 135: 149-157

Berghoff S.M., Weissflog A., Linsenmair K.E., Hashim, R. and Maschwitz U. 2002. Foraging of a hypogaeic army ant: a long neglected majority. Insect. Soc. 49: 133-141

Bestelmeyer B.T., Agosti D., Alonso L.E., Brandão C.R.F., Brown W.L., Delabie J.H.C. and Silvestre R. 2000. Field techniques for the study of ground dwelling ants. An overview, description, and evaluation. In: Ants: Standard Methods for Measuring and Monitoring Biodiversity (Agosti D., Majer J.D., Alonso L.E. and Schultz T.R., Eds), Smithsonian Institution Press, Washington London, pp 122-144

Bolton B. 1994. Identification Guide to the Ant Genera of the World. Harvard University Press, Cambridge London, $222 \mathrm{pp}$

Bolton B. 2003. Synopsis and Classification of Formicidae. Mem. Am. Entomol. Inst., Gainesville. 370 pp

Brandão C.R.F., Feitosa R.M., Schmidt F.A. and Solar R.R.C. 2008. Rediscovery of Simopelta minima (Brandão) (Hymenoptera, Formicidae), with a discussion on rarity and conservation of ant species. Rev. Bras. Entomol. 52: 480-483

Delabie J.H.C. and Fowler H.G. 1995. Soil and litter cryptic ant assemblages of Bahian cocoa plantations. Pedobiol. 39: 423-433

Elisson A.M., Record S., Arguello A. and Gotelli N.J. 2007. Rapid inventory of the ant assemblage in a temperate hardwood forest: species composition and assessment of sampling methods. Environ. Entomol. 36: 766-775

Fowler H.C. and Delabie J.H.C. 1995. Resource partitioning among epigaeic and hypogaeic ants (Hymenoptera: Formicidae) of a Brazilian cocoa plantation. Ecol. Austral. 5: 117-124

Fowler H.C., Delabie J.H.C. and Moutinho P.R.S. 2000. Hypogaeic and epigaeic ant (Hymenoptera: Formicidae) assemblages of Atlantic costal rainforest and dry mature and secondary Amazon forest in Brazil: Continuums or communities. Trop. Ecol. 41: 7380

Fundação Centro Tecnológico de Minas Gerais-CETEC. 1983. Diagnóstico ambiental do estado de Minas Gerais. Belo Horizonte. $158 \mathrm{pp}$

Greenslade P. and Greenslade P.J.M. 1971. The use of baits and preservatives in pitfall traps. J. Aust. Entomol. Soc. 10: 253-260

Hölldobler B. and Wilson E.O. 1990. The Ants. Belknap Press of Harvard University Press, Cambridge 732 pp

IBGE. 2004. Mapas de Biomas do Brasil. (ftp://ftp.ibge.gov.br/ Cartas_e_Mapas/Mapas_Murais/), Accessed 26 Oct. 2006.

Lobry de Bruyn L.A. 1999. Ants as bioindicators of soil function in rural environments. Agric. Ecosyst. Environ. 74: 425-441

MacKay W.P. 1996. A revision of the ant genus Acanthostichus (Hymenoptera: Formicidae). Sociobiology 27: 129-179.

MMA. 2007. Lista Nacional das Espécies da Fauna Brasileira Ameaçadas de Extinção. Ministério do Meio Ambiente. (http://www.mma.gov.br/port/sbf/fauna/index.cfm), Accessed 17 Aug. 2007

Oliveira P.S. and Del-Claro K. 2005. Multitrophic interactions in a neotropical savanna: ant-hemipteran systems, associated insect 
herbivores and host plant. In: Biotic Interactions in the Tropics: Their Role in the Maintenance of Species Diversity (Burslem D.F.R.P., Pinard M.A. and Hartley S.E., Eds), Cambridge University Press, Cambridge. pp 414-438

Olson D.M. 1991. A comparison of the efficacy of litter sifting and pitfall traps for sampling leaf litter ants (Hymenoptera: Formicidae) in a tropical wet forest, Costa Rica. Biotropica 23: 166172

Orbist M.K. and Duelli P. 1996. Trapping efficiency of funnel- and cup-traps for epigeal arthropods. Mitt. Schweiz. Entomol. Ges. 69: $361-369$

Palacio E.E. and Fernandéz F. 2003. Claves para las subfamilias y géneros. In: Introducción a las Hormigas de la Región Neotropical (Fernández F., Ed), Instituto Humboldt, Bogotá. pp 233-260

Porter S.D. 2005. A simple design for a rain-resistant pitfall trap. Insect. Soc. 52: 201-203

Rabeling C., Brown J.M. and Verhaagh M. 2008. Newly discovered sister lineage sheds light on early ant evolution. Proc. Natl. Acad. Sci. USA 30: 14913-14917

Ribas C.R., Schoereder J.H., Pic M. and Soares S.M. 2003b. Tree heterogeneity, resource availability, and larger scale processes regulating arboreal ant species richness. Austral Ecol. 28: 305-314

Ribas C.R., Sobrinho T.G., Schoereder J.H., Sperber C.F., LopesAndrade C. and Soares S.M. 2005. How large is large enough for insects? Forest fragmentation effects at three spatial scales. Acta Oecol. 27: 31-41

Ribas R.F., Meira-Neto J.A.A., Silva A.F. and Souza A.L. 2003a. Composição florística de dois trechos em diferentes etapas serais de uma Floresta Estacional Semidecidual em Viçosa, Minas Gerais. Rev. Árvore 27: 821-830

Schmidt F.A. and Diehl E. 2008. What is the effect of soil use on ant communities? Neotrop. Entomol. 37: 381-388
Schultz T.R. and McGlynn T.P. 2000. The interactions of ants with other organisms. In: Ants: Standard Methods for Measuring and Monitoring Biodiversity (Agosti D., Majer J., Alonso L.A. and Schultz T., Eds), Smithsonian Institution Press, Washington London. pp 35-44

Silva R.R. and Silvestre R. 2004. Riqueza da fauna de formigas (Hymenoptera: Formicidae) que habita as camadas superficiais do solo em Seara, Santa Catarina. Pap. Avulsos Zool. 44: 1-11

Sousa-Souto L., Schoereder J.H. and Schaefer C.E.G.R. 2007. Leafcutting ants, seasonal burning and nutrient distribution in Cerrado vegetation. Austral Ecol. 32: 758-765

Underwood E.C. and Fisher B.L. 2006. The role of ants in conservation monitoring: If, when and how. Biol. Conserv. 132: $166-182$

Valverde O. 1958. Estudo regional da Zona da Mata de Minas Gerais. Rev. Bras. Geogr. 20: 3-82

Veloso H.P., Rangel Filho A.L.R. and Lima J.C.A. 1991. Classificação da Vegetação Brasileira, Adaptada a um Sistema Universal. IBGE, Rio de Janeiro. 123 pp

Wang C., Strazanac J. and Butler L. 2001. A comparison of pitfall traps with bait traps for studying leaf litter communities. J. Entomol. Soc. Am. 94: 761-765

Weissflog A., Sternheim E., Dorow W.H.O., Berghoff S. and Maschwitz U. 2000. How to study subterranean army ants: a novel method for locating and monitoring field populations of the South East Asian army ant Dorylus (Dichthadia) laevigatus Smith, 1857 (Formicidae, Dorylinae) with observations on their ecology. Insect. Soc. 47: 317-324

Wilkie K.T.R., Mertl A.R. and Tranielo J.F.A. 2007. Biodiversity below ground: probing the subterranean ant fauna of Amazonia. Naturwissenschaften 94: 392-395

Wilson E.O. and Hölldobler B. 2005. Eusociality: Origin and consequences. Proc. Natl. Acad. Sci. USA 102: 13367-13371 